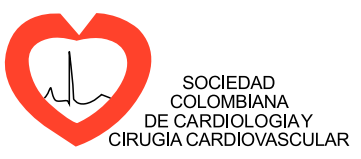

\title{
EDITORIAL
}

\section{The doctor of the plague}

\section{"Il dottore della peste"}

\author{
Manuel Giraldo-Grueso ${ }^{a, *}$, Darío Echeverri ${ }^{a}$, Rafael Conde ${ }^{b}$ \\ a FundaciónCardioinfantil - Instituto de Cardiología, Bogotá, Colombia \\ b Fundación Neumológica Colombiana, Bogotá, Colombia
}

Received 31 October 2017; accepted 2 November 2017

Over the years, pollution has gained greater importance due to its environmental aspect in large cities, the impact on global warming, and its leading role in several of the main causes of mortality, such as cardiovascular disease and cancer ${ }^{1}$.

Throughout the history of medicine, researchers have noted a direct relationship between air quality and health. It all began with the miasma theory ${ }^{2}$, which stated that diseases such as cholera, the black plague and malaria (from Italian words meaning "bad air), stemmed from contact with poisonous vapors known as "miasmä (from the Greek word for " contaminatioñ), a product of the putrefaction of matter. This led to the appearance of "il dottore della peste" in Venice in the 17th century: doctors garbed in a bird shaped mask with two lower holes full of spices, roses, herbs, and vinegar; a hat, and a robe, which helped them avoid these diseases that apparently were derived from contaminated air (fig. 1).

Winter of 1952 in London was an unforgettable season due to the increased local atmospheric contamination, together with a thermal inversion, which created the famous "great smoke" 3 : a dense air mass which prevented transit in the streets, triggered chaos in the city, and called into ques-

DOI of original article:

https://doi.org/10.1016/j.rccar.2017.11.001

* Corresponding author.

E-mail address: manuelgiraldog@hotmail.com (M. Giraldo-Grueso). tion the capacity to govern of Prime Minister Sir Winston Churchill. The city was cut off for four days. According to local statistics, more than 4,000 deaths were reported, and 12,000 people died in the following weeks and months due, to pulmonary problems ${ }^{3}$. Decades later, Clair Patterson, a geochemist at Caltech, California, discovered toxic levels of lead $(\mathrm{Pb})$ in the environment while calculating the age of the earth, using the analysis of zircon meteorites (Big Bang remnants). He showed that pre-industrial levels of lead were $0.0005 \mu \mathrm{g} / \mathrm{m}^{3}$, and that they rose to $1 \mu \mathrm{g} / \mathrm{m}^{3}$ in the $20^{\text {th }}$ century, causing anemias, neurological symptoms, and mental retardation. Consequently, he fought tirelessly against the automotive industry, to eradicate this particle from fuels ${ }^{4}$.

Currently, the adverse effects of exposure to the various solid or liquid contaminants dispersed in the atmosphere known as small particulate matter (PM) have caused great concern in governments and international organizations. This concern is not just because of the association of PM with respiratory diseases, but also due to the new available evidence regarding its relationship to cardiovascular symptoms ${ }^{1}$.

Sources of pollution can be divided into two groups: natural phenomena such as volcanoes and fires, and human causes such as carbon monoxide $(\mathrm{CO})$, sulfur dioxide $\left(\mathrm{SO}_{2}\right)$, or PM; all of them associated with increased mortality ${ }^{5}$. Particulate matter is classified according to size. Most is between $2.5-10 \mu \mathrm{m}$ and is deposited in the nasal cavity and upper respiratory tract. However, PM smaller than $2.5 \mu \mathrm{m}$ (PM 2.5), is able to travel throughout the airways, be deposited in the alveoli, and reach the blood flow through 


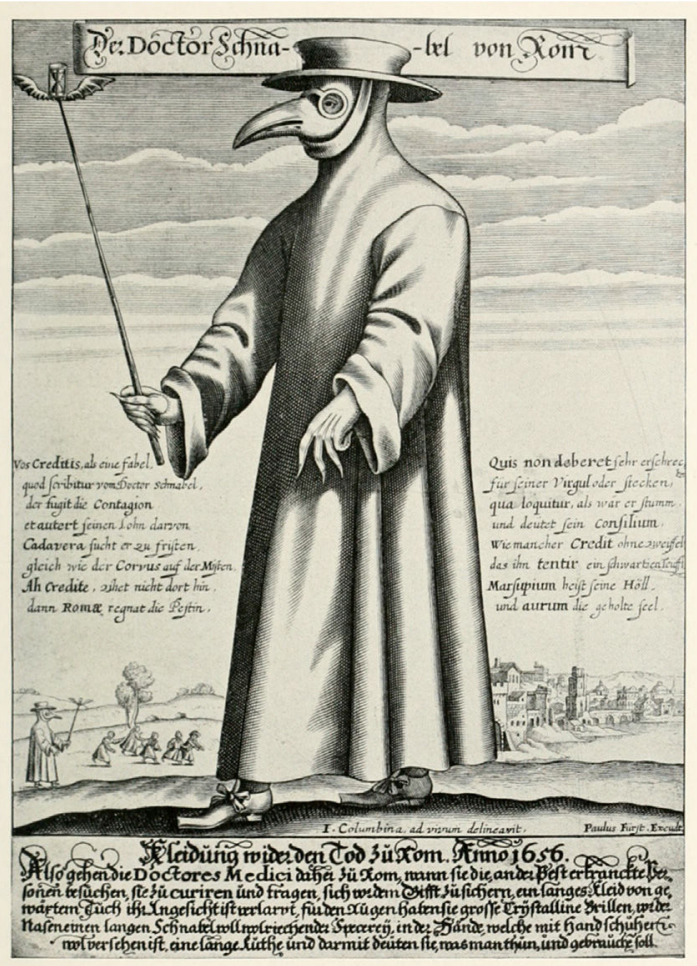

Figure 1 Paul Fürst, Der Doctor Schnabel von Rom. 1656. Copper engraving of "The Plague Doctor", in Rome. Image taken from Wikipedia, The plague doctor. Public domain image.

the pulmonary capillaries, where it is phagocytized by monocytes, causing local inflammation and oxidative stress, due to the activity of IL6, IL8, TNF $\infty$ and IF $\gamma$. These substances travel through the blood, activating acute phase reactants and platelets, creating hypercoagulable and vascular inflammatory response states, and increasing the risk of cardiovascular events ${ }^{1,5,6}$.

Studies such as the National Morbidity, Mortality and Air Pollution Study (NMMAPS) ${ }^{5}$, in which 50 million people living in 20 large cities of the metropolitan area of the United States were studied, have noted a $0.68 \%$ mortality increase due to cardiovascular causes on days with $P M>10 \mu \mathrm{g} / \mathrm{m}^{3}$. In 2004, Pope et al. reported a cohort of 500,000 patients with a 16 year follow-up, whose results suggested a significant increased risk of death due to ischemic cardiopathy [RR: $1.1295 \% \mathrm{Cl}(1.08-1.15)$ ] and arrhythmias [RR: $1.1395 \% \mathrm{Cl}$ (1.05-1.21)] after exposure to elevated levels of PM 2.5 (greater than $\left.10 \mu \mathrm{g} / \mathrm{m}^{3}\right)^{6}$.

With regard to arterial pressure, it has been shown that for every $10 \mu \mathrm{g} / \mathrm{m}^{3}$ increase in PM 2.5, there is a $2.8 \mathrm{~mm} \mathrm{Hg}$ increase in systolic pressure, and a $2.7 \mathrm{~mm} \mathrm{Hg}$ increase in diastolic pressure ${ }^{7}$. In addition, increased pollution has been shown to double the risk of obesity, pulmonary disease and cardiovascular death in older people ${ }^{8}$. Meanwhile, Davdand et al. ${ }^{9}$ carried out a case-control study for 10 years in Northern England, and they noted an increased risk of congenital heart defects in mothers exposed to various contaminants. Mothers exposed to $\mathrm{SO}_{2}$ had a significantly increased risk of congenital heart defects such as ventricular septal defects [OR: $2.695 \% \mathrm{Cl}(1.8-3.7)]$.
The most recent Global Burden of Disease (GBD) ${ }^{10}$ analysis found that exposure to PM 2.5 was responsible for 4.2 million deaths in 2015, and was the fifth most important risk factor for death due to cardiovascular disease, lung disease, cancer, and cerebrovascular accidents, due to the hypercoagulability it causes. Landrigan et al. suggested that contamination is responsible for $16 \%$ of annual deaths, in addition to nine million premature deaths, and causes 15 times more deaths than war, and three times more than AIDS, tuberculosis and malaria combined ${ }^{11}$.

In 2016, the World Health Organization (WHO), estimated that only one out of 10 people breathes clean air $^{12}$. Environmental factors are to blame for $24 \%$ of the global burden of disease, with air pollution being considered responsible for 3.2 million deaths per year, and $3.1 \%$ of the total daily deaths. According to this organization, $94 \%$ of deaths worldwide are related to environmental pollution. Of this percentage, $72 \%$ are due to cardiovascular diseases (cerebrovascular accidents $36 \%$ and ischemic cardiopathy $36 \%$ ), followed by $14 \%$ due to lung cancer and $8 \%$ due to chronic obstructive pulmonary disease ${ }^{12}$.

As a consequence, health care costs secondary to pollution come to 4.6 trillion dollars a year, $6.2 \%$ of the global economy ${ }^{11}$. In Colombia, the Departamento Nacional de Planeación [National Planning Department] reported that healthcare costs due to environmental deterioration totaled 20.7 billion pesos in 2015 , equivalent to $2.6 \%$ of the gross national product ${ }^{13}$. In the United States, prevention and the reduction of pollution has saved 200 billion dollars each year since 1980 (a total of six trillion dollars) ${ }^{11}$.

The goal for WHO is levels of PM $2.5<10 \mu \mathrm{g} / \mathrm{m}^{3}$. According to Real Time Air Quality Index (http://aqicn. $\mathrm{org} / \mathrm{map} /$ world/ ), in Colombia, specifically in Bogotá, average levels of PM between 24 and $145 \mu \mathrm{g} / \mathrm{m}^{3}$ are recorded throughout the day, with morning hours being the critical contamination point (fig. 2). Other Latin American countries also have high pollution levels compared with other world capitals. The cited index shows how Sao Paulo has an average of $155 \mu \mathrm{g} / \mathrm{m}^{3}$, while Buenos Aires has $112 \mu \mathrm{g} / \mathrm{m}^{3}$ (fig. 3). The concentration of PM is increasing rapidly, and an $11.2 \%$ increase worldwide was seen from 1990 to $2015^{10}$.

Organizations such as WHO and the Ambient Air Pollution Expert Group have undertaken actions with regard to this subject, with individual and collective approaches. In the first case, change is based on prevention. Countries with high contamination prefer to have their employees work from home on days when pollution is high; they close schools, limit traffic and promote the use of masks. However, this has not impacted pollution-generated mortality, and it encourages a certain type of sedentarism ${ }^{14}$. Collectively, it is proposed that governments generate new policies based on their levels of contamination. New Delhi intends to decrease its PM 2.5 levels by $70 \%$ in the next few years. However, we still find world powers who are skeptical about pollution and climate change.

Our own future is in our hands, as a society. We cannot continue accumulating cardiovascular risks and decreasing quality of life. We are at a critical juncture for educating our students on this subject in the classroom, participating in community awareness raising campaigns, and monitoring and supporting government policies for environmental protection. Otherwise, at this rate, in the future we will wear 


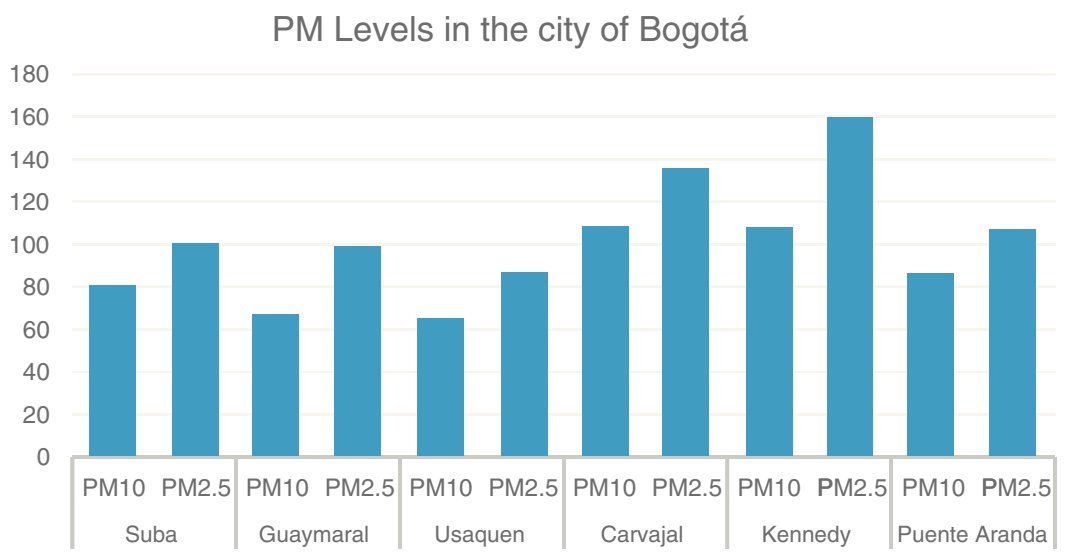

Figure 2 Levels of contamination in the city of Bogotá, measured in $\mu \mathrm{g} / \mathrm{m}^{3}$. Taken from Real Time Air Quality Index. September 26/2017, 7:00am.

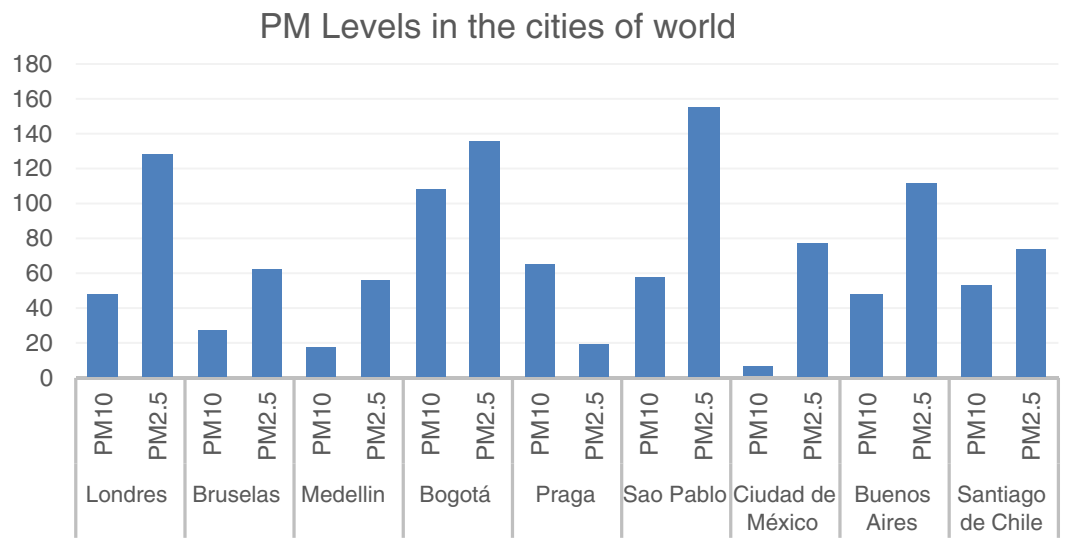

Figure 3 Contamination levels in cities of the world, measured in $\mu \mathrm{g} / \mathrm{m}^{3}$. Taken from Real Time Air Quality Index. September 26/2017, 7:00am.

special masks with two holes for air intake and purification, robes, and a hat, to avoid a real miasma, and we will be the modern satire of "il dottore della peste".

\section{References}

1. Byeong-Jae L, Bumseok K, Kyuhong L. Air pollution exposure and cardiovascular disease. Toxicol Research. 2014;30:71-5.

2. Karamanou M, Panayiotakopoulos G, Tsoucalas G, Kousoulis AA, Androutsos G. From miasmas to germs: a historical approach to theories of infectious disease transmission. Infez Med. 2012;20:58-62.

3. Bharadwaj P, Graff J, Mullins JT, Neidell M. early life exposure to the great smog of 1952 and the development of asthma. Am J Respir Crit Care Med. 2016;194:1475-82.

4. Hernberg S. Lead poisoning in a historical perspective. Am J Med. 2000;38:244-54.

5. Samet JM, Dominici F, Zeger SL, Schwartz J, Dockery DW. The National Morbidity, Mortality, and Air Pollution Study. Part I: Methods and methodologic issues. Res Rep Health Effect Inst. 2000; 94 Pt 1:5-14, discussion 75-84.

6. Arden Pope C, Burnett RT, Thurston GD, Thun MJ, Calle EE, Krewski D, et al. Cardiovascular mortality and long-term exposure to particulate air pollution: epidemiological evidence of general pathophysiological pathways of disease. Circulation. 2004;109:71-7.

7. Brook RD. Why physicians who treat hypertension should know more about air pollution. J Clin Hypertens. 2007;9:629-35.

8. Peel JL, Metzger KB, Klein M, Flanders WD, Mulholland JA, Tolbert P. Ambient air pollution and cardiovascular emergency department visits in potentially sensitive groups. Am J Epidemiol. 2007;165:625-33.

9. Dadvand P, Rankin J, Rushton S, Pless-Mulloli T. Ambient air pollution and congenital heart disease: A register-based study. Environ Res. 2011;111:435-41.

10. State of the global air 2017, a special report on global exposure to air pollution and its disease burden. Disponible en: http://www.ccacoalition.org/en/resources/state-globalair-2017-special-report-global-exposure-air-pollution-and-itsdisease-burden. [Acceso 28 Sep 2017].

11. Landrigan P, Fuller R, Acosta N, Adeyi O, Arnold R, Basu N, et al. The lancet commission on pollution and health. The Lancet doi.org/10.1016/S0140-6736(17)32345-0.

12. World Health Organization. Ambient air pollution: A global assessment of exposure and burden of disease. WHO. World Health Organization; 2016. Disponible en: http: / /apps. who.int/ iris/bitstream/10665/250141/1/9789241511353-eng.pdf. [Acceso 24 Oct 2017].

13. Los costos en la salud asociados a la degradación ambiental en Colombia ascienden a $\$ 20,7$ billones. Disponible en: https:// 
www.dnp.gov.co/Paginas/Los-costos-en-la-salud-asociadosa-la-degradaci\%C3\%B3n-ambiental-en-Colombia-ascienden-a\$20,7-billones-.aspx. [Acceso 20 Oct 2017].
14. Laumbach R, Meng Q, Kipen $\mathrm{H}$. What can individuals do to reduce personal health risks from air pollution? J Thorac Dis. 2015;7:96-107. 